\title{
Cyprideis torosa: a model organism for the Ostracoda?
}

\author{
Patrick De Deckker ${ }^{\text {* }}$ \& Alan Lord ${ }^{2 *}$ \\ ${ }^{1}$ Research school of Earth Sciences, The Australian National University, Canberra ACT 2601, Australia \\ ${ }^{2}$ Senckenberg Forschungsinstitut, Senckenberganlage 25, D-60325 Frankfurt-am-Main, Germany \\ *Correspondence: patrick.dedeckker@anu.edu.au; alan.lord@senckenberg.de
}

In 1990 Danielopol et al. described the ostracod genus Cytherissa as 'the Drosophila of paleolimnology' in the sense of a model organism for their purposes at that time. In the intervening years Drosophila is no longer seen by biologists as the perfect test model and, for example, the nematode worm Caenorhabditis elegans is now viewed as preferable because "the fly is much more complex than the worm and the anatomy of the nervous system has not reached the level of completeness achieved for the worm' (Brenner 2003, p. 278). For some years attention has focused on Cyprideis torosa (Jones, 1850), especially since the pioneering work of Rosenfeld \& Vesper (1977) on sieve-pore variability in this species in relation to salinity, because torosa is a particularly widely distributed euryhaline living and fossil ostracod species. Cyprideis torosa is not only biogeographically widespread but occurs in a salinity range from freshwater to hypersaline, tolerates a wide range of temperature, oxygen and substrate conditions, and also has a large, well-calcified and easily preserved carapace. The species first occurs in sedimentary formations of early Pleistocene age but may be older. Therefore, it has the potential to be an ostracod model organism. This set of thematic papers is designed to summarize our current knowledge of one of the most important living ostracod species, its distribution, ecology, morphological response to environmental pressures, and molecular characterization, together with our understanding of its origins and value for palaeoenvironmental interpretation. The ultimate aim is to define potentially rewarding research targets using $C$. torosa as a model organism.

\section{Layout}

The papers herein were first published electronically (see data on individual papers) reflecting the order in which manuscripts were submitted, reviewed and accepted. Thus, later authors had the benefit of being able to read and cite papers already published Online First. Since manuscripts were handled editorially piecemeal there are inconsistencies evident that we hope the reader will forgive, especially in relation to citation of salinity (see below). In the printed part, we have rearranged the papers into what we consider to be a more logical sequence.

\section{Salinity}

Salinity is cited in a variety of ways in the literature and herein: '\%o' 'psu' 'ppm' and ' $\mathrm{S}$ '. Salinity is a ratio and requires no units; however, ARL has respected author preferences in the submitted manuscripts especially when salinity has been quoted from literature or other older sources. It is also very important to know and record how salinity was measured, especially since several references relate to work performed several decades ago. For instance, salinity could be established by weighing the total residue left after evaporating water, and thus salinity was listed as the amount of Total Dissolved Solids [=TDS], but we now know that organic compounds will occur among the post-evaporation residue, and this does not directly relate to water salinity. Measuring electrical conductivity has been for many decades the preferred method for calculating salinity, but this is based on waters having a $\mathrm{NaCl}$ dominance, and tables have become available to relate water salinity to electrical conductivity. Nevertheless, some saline waters may be dominated by different ions, such as sodium carbonate, calcium sulphate etc., and therefore salinity calculated by correlation with electrical conductivity has to be carefully assessed. Nevertheless, it is clearly established that torosa and, by similarity, other Cyprideis species - all being of marine ancestry - are found in the alkalinity-depleted chemical pathway of waters as defined by Eugster \& Jones (1979) which are dominated by $\mathrm{Na}$ and $\leq \mathrm{Cl}$ ions.

The reason for establishing the salinity of the water in which the ostracod lived is rather important when assessing osmoregulation processes, and when linking salinity changes to climatic and environmental changes. The latter two parameters are also of direct relevance when studying fossil ostracod material.

\section{The papers}

As will become clear, for obvious reasons, this set of papers is dedicated to our late colleague Amnon Rosenfeld (1944-2014); see Keyser \& Honigstein (2016).

Frogley \& Whittaker (2016) discuss the original description of C. torosa from Pleistocene deposits on the Thames Estuary (UK), refigure the original illustrations and the scanning electron micrographs of lectotypic material of Kilenyi \& Whittaker (1974) and briefly outline the career of the describer of the species Thomas Rupert Jones (1819-1911). Kempf (2016) complements the historical dimension with a review of the nomenclature and taxonomy of C. torosa since its description.

Wouters (2016) brings up to date his earlier surveys of the biogeographical distribution of living C. torosa (Wouters 2002, 2003) in Europe, Africa and Asia and raises the question of the presence, or not, of the species in Australia. Schön, Halse \& Martens (2017) use molecular phylogenetic methods to investigate the occurrence of torosa in Australia, concluding that the species is not present and that two other different species are probably present on the continent, thereby demonstrating that torosa is not a cosmopolitan species.

From its well-calcified valves and common occurrence torosa is an attractive subject for geochemical study (trace-elements and stable-isotopes) and Holmes \& De Deckker (2016) review data from specimens from in vitro cultures and a range of natural environments. This paper clearly identifies that there are still several unknowns about ostracod shell composition and its relationship to ambient conditions, and therefore calls for additional investigations. Thus, in an application of trace-element chemistry Wansard, De Deckker \& Julià (2016) combined with the pioneer work of Heip $(1976 a, b)$, who measured ambient water temperature for torosa 
over a four-year period in a brackish pond in northern Belgium, to analyse $\mathrm{Mg} / \mathrm{Ca}$ of torosa adult valve calcification in Lake Banyoles (NE Spain). The modern temperature relationship of $\mathrm{Mg} / \mathrm{Ca}$ for torosa was then used to reconstruct a $28 \mathrm{kyr}$ palaeotemperature history of the lake from core material.

Three papers investigate the relationships between carapace characteristics and salinity. Frenzel, Ewald \& Pint (2016) describe experiments with cultured torosa material to broadly confirm the relationship between sieve-pore shape and salinity recognized by Rosenfeld \& Vesper (1977) in the oligohaline to mesohaline range; however, the stability of the host water body seems to be a factor. Boomer, Frenzel \& Feike (2016) analyse the relationship between size (as length, length/height) and salinity and show that while there is a relationship it is not a simple quantitative one, but a number of questions are raised about a complex relationship in need of further research. Grossi, Da Prato \& Gliozzi (2016) apply morphometrics to understand the relationship between salinity and the valve outline of living and Recent (sub-fossil) torosa from Italy, concluding that two morphotypes can be recognized: forms with a straight ventral margin from oligohaline waters and forms with a more sigmoidal ventral margin profile apparently related to higher salinity waters.

Carapace characteristics of living and Recent torosa are analysed by Gliozzi, Rodriguez-Lazaro \& Pipik (2016) in order to clearly define the species for comparison with fossil Cyprideis forms. By this means Cyprideis gr. torosa is recognized in the Palaeomediterranean late Tortonian (late Miocene) and C. torosa sensu stricto appears to have evolved in the early Calabrian (early Pleistocene).

Cabral, Fatela, Lopes, Freitas \& Andrade (2016) provide a very full account of living and Holocene torosa from mainland Portugal, the living material analysed as adults and juveniles from lagoons and estuaries, with associated ostracod species documented. Pint \& Frenzel (2016) focus on taxa occurring with torosa as important guides to salinity variations in the host milieu, given that torosa is usually monospecific only in hypersaline waters. Scharf, Herzog \& Pint (2016) review the occurrence of torosa and associated taxa in German coastal waters and especially from natural and anthropogenic saline waters in central Germany.

Appropriately the final paper returns to the type area of Cyprideis torosa, the Thames Estuary. Horne, Benardout \& Whittaker (2016) examine the occurrence of torosa and associated ostracods from (marine isotope stage) MIS 9 and MIS 11 interglacial deposits of the early Thames-Medway river system by comparison with the study of ostracod biofacies in the modern Thames Estuary of Kilenyi (1969).

\section{Quo vadis Cyprideis torosa?}

Upon reading the articles presented in this volume, it is clear that Cyprideis torosa needs to be further investigated so as to render this species a better biological, geological and environmental indicator. Below, we suggest several topics which we consider to be worth pursuing so as to better understand this species.

\section{Noding}

The formation of nodes in torosa has now been finally resolved and interpreted by Keyser \& Aladin (2004) and Keyser (2005). The latter paper demonstrates that the changes in ornamentation and the cellular layers of the epidermis occur in areas of the valves and underlying epidermis that are linked. The same author (Keyser 2005) postulated that noding is caused by the inability of the ostracod to regulate its internal osmotic pressure during moulting in low salinity waters $(<\sim 6)$. Keyser (2005) concluded that this must therefore be considered as a phenotypic rather than genetic response. This is in contrast to what had been previously postulated (see discussion in Keyser 2005, pp. 100-101). Keyser (2005, p. 101) clearly defined that 'nodes occur only outside the isthmus of the shell when the outer and inner epidermal cell layer are connected'. When raising the ambient osmosalinity in the body fluid during moulting, pressure disrupts the old cuticle on the edge of the calcified zone. Further, Keyser \& Aladin (2004), through analysis of micro-cryoscopic measurements of the internal osmoregulation, found that at salinities below 6.2, the osmolarity of the hemolymph in torosa results from a hyperosmotic condition, whereas above that value, the conditions are isosmotic. The upper salinity value for the waters in which ostracods were analysed by Keyser \& Aladin (2004) was 44. There is nevertheless a need to investigate the occurrence of nodation at a much higher salinity (up to 96) in which Schonikov (1973) found noded torosa in the Aral Sea. Is isosmotic condition still prevalent in water salinities as high as three times that of seawater?

Despite the fact that Keyser \& Aladin (2004) indicated that torosa has problems with osmoregulation, the presence of nodes on valves can still be assumed to infer low salinities $(<6)$ if the nodation at the Aral Sea site of Schonikov (1973) is to be explained. The processes involved in the formation of nodes in torosa are elegantly presented with clear and ample illustrations in Keyser (2005) and Keyser \& Aladin (2004). Finally, we wish to query the statement made by Keyser (2005, p. 106) when he discusses noding that the moulting process is interlinked due to 'low amounts of calcium ions within the animal, reducing sharply the flexibility of desmosomes and muscles'. We suggest that additional investigation should concentrate on the composition of the hemolymph fluid, so as to determine if the alkalinity of this fluid (via $\mathrm{HCO}_{3}$ ) may, in fact, be the controlling factor (see further discussion below).

\section{Long-term ecological observations}

Vesper $(1972 a, b)$ carried out a very detailed analysis of the morphology and ecology of torosa (along the River Schlei and areas in the Schleswig-Holstein region, northern Germany) which was almost coincident with the study made by Heip (1976a, $b$; Herman \& Heip 1982; Heip in Herman et al. 1983), who continuously sampled torosa in a brackish-water site (Dievengat, northern Belgium), which also occurs in the cold, nearctic region of Europe. There is, therefore, a need to carry out a similar long-term study of torosa under the influence of a Mediterranean climate under which temperature regimes, alkalinity, $\mathrm{pCO}_{2}$ and water chemistry composition would vary differently from the Belgian and German sites. For example, Heip (1976a), who identified that torosa is a detritivore that feeds principally on the vast bacterial biomass, pointed out that at higher temperatures such a biomass would be enhanced. This needs to be investigated in areas such as the Camargue in the Rhône Delta and the salinas of the Santa Pola region in northwestern Spain where torosa commonly abounds in saline lakes.

Heip (1976a) identified that temperature is the most important factor influencing the life cycles of torosa, for which ostracod larval development lasted 129-152 days over 3 years, with no adult lasting into the second year. Would a similar life strategy occur under the warmer Mediterranean climate?

It is unfortunate that neither Vesper nor Heip measured alkalinity of the waters during their long investigations of the life cycles of torosa, and this needs to be examined in the future so as to better understand ostracod shell composition. Alkalinity, combined with ionic analysis of the ambient waters will lead to identification of the calcite saturation nature of the waters in which ostracods moult and grow. Some of these parameters may be important factors controlling ostracod valve calcification and also perhaps hemolymph composition that in turn is now known to affect the nodosity 
of torosa. We may have to wait until analytical techniques are improved to enable us to measure alkalinity in such small samples, but perhaps the use of tiny $\mathrm{pH}$ electrodes would already suffice to establish alkalinity levels in the hemolymph.

\section{Productivity}

Concerning the productivity studies of torosa in Dievengat by Heip $(1976 a, b)$ and Herman et al. (1983), figures are staggering. Two methods used to establish production of torosa return values of 9.7 and $9.2 \mathrm{~g}$ of dry weight per $\mathrm{m}^{2}$ per year, with even a total biomass value once found by Heip (1976b) reaching $48.9 \mathrm{~g}$ dry weight per $\mathrm{m}^{2}$ per year; an amazing phenomenon which clearly identifies that torosa is on top of the food chain (Heip 1976a,b). This author also showed that the number of individuals found in his four-year sampling varied between 20000 and 40000 individuals per $\mathrm{m}^{2}$ with, in one instance, numbers reaching 1.8 million specimens per $\mathrm{m}^{2}$ (at that time adult specimens amounted to $c .15 \%$ of the population). It is interesting to note, therefore, that the level of calcium and bicarbonate of the water in which torosa live in large numbers need to be constantly high. Geochemical analysis of ostracod valves, such as $\delta^{13} \mathrm{C}$ for comparison against dissolved inorganic carbon (DIC) composition, should also guide us to establish past productivity levels at fossil sites.

\section{Temperature requirements}

Heip (1976a) also identified that moulting to adulthood can occur at Dievengat only once the ambient water temperature is above $15^{\circ} \mathrm{C}$. Hence, the following question can be asked: is the temperature requirement the same for other locations, or remained the same during glacial/colder periods? Wansard et al. (2016) already considered this issue for the glacial period in Lake Banyoles in northern Spain where torosa was found to thrive.

\section{Genetic investigations and passive transport}

The genetic differentiation of torosa needs to be further documented. Already, Sywula et al. (1995) have found two distinct genetic populations, one along the coasts of England and The Netherlands, and the other along the southern coast of the Baltic Sea. Such a surprising find challenges the concept that a continuous exchange of gene pool exists, via passive transport [see Sandberg \& Plusquellec (1974) for a thorough review of dispersal processes, although they did not cite transport by boats and fishing equipment between different water bodies], so a north-south transect from the Nearctic down to at least Lake Turkana in Kenya where torosa occurs (see Sywula et al. 1995) would help identify the likely presence of several gene pools that may be linked to bird pathways and the presence of past environmental conditions, such as glacial erosion, and climatic events. Van Harten (1996) already invoked this when considering the transient and balanced genetic polymorphism and environmentally-cued capability of forming nodes on torosa originally postulated by Kilenyi (1972). Schön et al. (2017) used a different approach to Sywula et al. (1995) (namely DNA extraction for several Australian taxa) who carried out an electrophoretic survey of allozyme variation.

It is clear that further genetic studies are essential to resolving questions of gene pools, of the number of cryptic species present and relationships between Cyprideis torosa and other congeners in Europe and surrounding regions, as well as for the numerous Cyprideis species now reported from the Americas (see Sandberg 1964; Sandberg \& Plusquellec 1974). This may also help to determine the evolutionary origin of torosa itself.

\section{Brood care}

Finally, brood care is an important characteristic of the life strategy of torosa. Already, Sandberg (1964) has discussed this phenomenon which had been recognized as far back as 1866 by G.O. Sars (see Sandberg's 1964 review, p. 53). Sandberg \& Plusquellec (1974) showed this to offer a distinct advantage for dispersal that can also help the ostracod tolerate environmental stresses (such as salinity change, anoxic condition, as well as temporary desiccation conditions). Also, can we establish the diet of the instars remaining inside the carapace of the adult mother? What is the chemical composition of the instar valves, in particular with respect to $\delta^{13} \mathrm{C}$ ? Surprisingly, neither Heip (1976a, b) nor Vesper (1972a) discuss the brood care phenomenon. More research is required considering brood care in Cyprideis, which as a genus is never found in ephemeral waters; it clearly inhabits permanent waters.

\section{Shell chemistry}

Already, Meyer et al. (2016) have compared morphological and geochemical variations in two species of Cyprideis (C. salebrosa and $C$. americana) in the neotropics of the Americas and showed changes in calcite saturation between two seasons in Shell Creek of Florida (with only two analyses, unfortunately). Such a change could be of importance to explain the $\delta^{13} \mathrm{C}$ and $\delta^{18} \mathrm{O}$ composition of ostracod shells. What these authors did not investigate is exactly where Cyprideis valves are calcified. We already know that torosa, for example, is part of the meiofauna (Heip 1976a, b; Herman et al. 1983 ) and that the chemical composition of pore fluids may have a different composition with respect to $\delta^{13} \mathrm{C}$ compared to the supernatant water. The important work of Decrouy et al. (2011) at Lake Geneva/Leman in Switzerland indicates that pore fluids may have a different composition from the supernatant water and consequently ostracod valve composition with respect to $\delta^{13} \mathrm{C}$ relates to pore water isotopic composition for forms dwelling interstitially. This phenomenon may explain why Marco-Barba et al. (2012), who analysed the isotopic composition of torosa from several water bodies near Valencia in Spain, showed no correlation with the ambient waters that they analysed. Perhaps this may explain also why those authors mentioned above found no correlation between the $\mathrm{Mg} / \mathrm{Ca}$ of ostracod valves and water temperature, in contrast with the in vitro experiments made by De Deckker et al. (1999) on the Australian species C. australis (see Schön et al. (2017) for the taxonomic discussion of this species). An important question remains: was the $\mathrm{Mg} / \mathrm{Ca}$ of the pore waters of the Valencia lakes the same as those of the measured lake waters? Nevertheless, Marco-Barba et al. (2012) reported that the $\delta^{13} \mathrm{C}$ of torosa in the Valencia lakes is c. $2 \%$ lower than expected from the $\delta^{13} \mathrm{C}$ of the dissolved inorganic carbon of the lake water, from which these authors conclude that calcification must take place infaunally.

\section{And finally}

Concerning the estimation of the alkalinity of the waters in which torosa thrives, it may be possible to investigate the $\mathrm{B} / \mathrm{Ca}$ and the boron isotopic composition of ostracod valves, such as has been carried out for foraminifera (Rae et al. 2011) and corals (Pelejero et al. 2005) as a proxy for water alkalinity. The increase in atmospheric $\mathrm{CO}_{2}$ since the beginning of the industrial revolution may already affect the distribution of torosa in some water bodies. This may explain, for example, why Pint et al. (2012) failed to find live specimens of torosa in inland waters in Germany (up to $300 \mathrm{~km}$ from the coast) whereas in such areas ample fossil torosa material was found in Holocene and interglacial deposits.

Obviously, for environmental monitoring, additional physicochemical parameters need to be acquired to render torosa an 
excellent (palaeo)environmental indicator. This issue of Journal of Micropalaeontology is a step towards this goal.

\section{Acknowledgements and Funding}

ARL acknowledges Patrick De Deckker for the initial inspiration for this thematic set of papers on Cyprideis torosa and for his long-term support. PDD and ARL both acknowledge Dan Danielopol (University of Graz) as an unfailing source of ideas and inspiration! We both thank our Contributing Authors, the Reviewers, and especially Sarah Gibbs our Senior Production Editor.

\section{References}

Boomer, I., Frenzel, P. \& Feike, M. 2016. Salinity-driven size variability in Cyprideis torosa (Ostracoda, Crustacea). Journal of Micropalaeontology, first published online July 4, 2016, https://doi.org/10.1144/jmpaleo2015-043

Brenner, S. 2003. Nature's gift to Science (Nobel lecture December 8, 2002). In: Frängsmyr, T. (ed.) Les Prix Nobel. The Nobel Prizes, 2002. Nobel Foundation, Stockholm, 274-282.

Cabral, M.C., Fatela, F., Lopes, V., Freitas, M.C. \& Andrade, C. 2016. Cyprideis torosa (Jones, 1850) in mainland Portugal: what do we know? Journal of Micropalaeontology, first published online August 15, 2016, https://doi.org/ 10.1144/jmpaleo2015-031

Danielopol, D.L., Carbonel, P. \& Colin, J-P. 1990. Cytherissa (Ostracoda). The Drosophila of paleolimnology. Metaphore and reality. Bulletin de l'Institut de Géologie du Bassin d'Aquitaine, 47/48, 297-310.

Decrouy, L., Vennemann, T.W. \& Ariztegui, D. 2011. Controls on ostracod valve geochemistry: Part 2. Carbon and oxygen isotope compositions. Geochimica et Cosmochimica Acta, 75, 7380-7399.

De Deckker, P., Chivas, A.R. \& Shelley, J.M.G. 1999. Uptake of Mg and $\mathrm{Sr}$ in the euryhaline ostracod Cyprideis determined from in vitro experiments. Palaeogeography, Palaeoclimatology, Palaeoecology, 148, 105-116.

Frenzel, P., Ewald, J. \& Pint, A. 2016. Salinity-dependent sieve pore variability in Cyprideis torosa: an experiment. Journal of Micropalaeontology, first published online December 7, 2016, https://doi.org/10.1144/jmpaleo2016-009

Frogley, M.R. \& Whittaker, J.E. 2016. On the origins of Cyprideis torosa (Jones, 1850) and a short biography of Professor T. R. Jones. Journal of Micropalaeontology, first published online March 30, 2016, https://doi.org/ 10.1144/jmpaleo2015-023

Eugster, H.P. \& Jones, B.F. 1979. Behavior of major solutes during closed-basin brine evolution. American Journal of Science, 279, 609-631.

Gliozzi, E., Rodriguez-Lazaro, J. \& Pipik, R. 2016. The Neogene Mediterranean origin of Cyprideis torosa (Jones, 1850). Journal of Micropalaeontology, first published online December 22, 2016, https://doi.org/10.1144/jmpaleo2016-029

Grossi, F., Da Prato, S. \& Gliozzi, E. 2016. Is the occurrence of a sigmoidal ventral border in Cyprideis torosa (Jones) valves linked to salinity? A morphometrical analysis approach. Journal of Micropalaeontology, first published online December 22, 2016, https://doi.org/10.1144/jmpaleo2016-018

Heip, C. 1976a. The life-cycle of Cyprideis torosa (Crustacea, Ostracoda). Oecologia, 24, 229-245.

Heip, C. 1976b. The spatial pattern of Cyprideis torosa (Jones, 1850) (Crustacea: Ostracoda). Journal of the Marine Biological Association of the United Kingdom, 56, 179-189.

Herman, P.M.J. \& Heip, C. 1982. Growth and respiration of Cyprideis torosa Jones, 1850 (Crustacea, Ostracoda). Oecologia, 54, 300-303.

Herman, P.M.J., Heip, C. \& Vranken, G. 1983. The production of Cyprideis torosa Jones, 1850 (Crustacea, Ostracoda). Oecologia, 58, 326-321.

Holmes. J.A. \& De Deckker, P. 2016. Trace-element and stable-isotope composition of the Cyprideis torosa (Crustacea, Ostracoda) shell. Journal of Micropalaeontology, first published online May 24, 2016, https://doi.org/10. 1144/jmpaleo2015-024

Horne, D.J., Benardout, G. \& Whittaker, J.E. 2016. Cyprideis torosa (Jones, $1850)$ in its type area and stratigraphical context: potential for mapping the freshwater/estuarine boundaries of the Thames-Medway river system in the MIS 9 and MIS 11 interglacials. Journal of Micropalaeontology, first published online August 15, 2016, https://doi.org/10.1144/jmpaleo2015-037

Jones, T.R. 1850. Description of the Entomostraca of the Pleistocene Beds of Newbury, Copford, Clacton, and Greys. Annals and Magazine of Natural History (Series 2), 6, 25-28.

Kempf, E.K. 2016. Historical development of nomenclature and taxonomy of Cyprideis torosa (Ostracoda). Journal of Micropalaeontology, first published online May 24, 2016, https://doi.org/10.1144/jmpaleo2016-011

Keyser, D. 2005. Histological pecularities of the noding process in Cyprideis torosa (Jones) (Crustacea, Ostracoda). Hydrobiologia, 538, 95-106.

Keyser, D. \& Honigstein, A. 2016. Dedication: Dr Amnon Rosenfeld 1944-2014. Journal of Micropalaeontology, first published online December 22, 2016, https://doi.org/10.1144/jmpaleo2015-011
Keyser, D. \& Aladin, N. 2004. Noding in Cyprideis torosa and its causes. Studi Quaternaria, 21, 19-24.

Kilenyi, T.I. 1969. The problems of ostracod ecology in the Thames Estuary. In Neale, J.W. (ed.) The Taxonomy, Morphology and Ecology of Recent Ostracoda. Oliver \& Boyd, Edinburgh, 251-267.

Kilenyi, T.I. 1972. Transient and balanced genetic polymorphism as an explanation of variable noding in the ostracode Cyprideis torosa. Micropaleontology, 18, 47-63.

Kilenyi, T.I. \& Whittaker, J.E. 1974. On Cyprideis torosa (Jones). A Stereo-Atlas of Ostracod Shells, 2, 21-32.

Marco-Barba, J., Ito, E., Carbonell, E. \& Mesquita-Joanes, F. 2012. Empirical calibration of shell chemistry of Cyprideis torosa (Jones, 1850) (Crustacea, Ostracoda). Geochimica et Cosmochimica Acta, 93, 143-163.

Meyer, J., Wrozyna, C., Gross, M., Leis, A. \& Piller, W.E. 2016. Morphological and geochemical variations of Cyprideis (Ostracoda) from modern waters of the northern Neotropics. Limnology, first published online October 6, 2016, https://doi.org/10.1007/s10201-016-0504-9

Pelejero, C., Calvo, E., McCulloch, M.T., Marshall, J.F., Gagan, M.K., Lough, J. M. \& Opdyke, B.N. 2005. Preindustrial to modern interdecadal variability in coral reef pH. Science, 309, 2204-2206, https://doi.org/10.1126/science. 1113692

Pint, A. \& Frenzel, P. 2016. Ostracod fauna associated with Cyprideis torosa - an overview. Journal of Micropalaeontology, first published online December 8 , 2016, https://doi.org/10.1144/impaleo2016-010

Pint, A., Frenzel, P., Fuhrmann, R., Scharf, B. \& Wennrich, V. 2012. Distribution of Cyprideis torosa (Ostracoda) in Quaternary athalassic sediments in Germany and its application for palaeoecological reconstructions. International Review of Hydrobiology, 97, 330-355.

Rae, J.W.B., Foster, G.L., Schmidt, D.N. \& Elliott, T. 2011. Boron isotopes and $\mathrm{B} / \mathrm{Ca}$ in benthic foraminifera: Proxies for the deep ocean carbonate system. Earth and Planetary Science Letters, 302, 403-413.

Rosenfeld, A. \& Vesper, B. 1977. The variability of the sieve-pores in Recent and fossil species of Cyprideis torosa (Jones, 1850) as an indicator for salinity and palaeosalinity. In: Löffler, H. \& Danielopol, D.L. (eds) Aspects of Ecology and Zoogeography of Recent and Fossil Ostracoda. Dr W. Junk b.v., The Hague, 55-67.

Sandberg, P.A. 1964. The Ostracod Genus Cyprideis in the Americas. Acta Universitatis Stockholmiensis, Stockholm Contributions in Geology, 12, $1-178$.

Sandberg, P.A. \& Plusquellec, P.L. 1974. Notes on the anatomy and passive dispersal of Cyprideis (Cytheracea, Ostracoda). Geoscience and Man, 6, 1-26.

Scharf, B., Herzog, M. \& Pint, A. 2016. New occurrences of Cyprideis torosa (Crustacea, Ostracoda) in Germany. Journal of Micropalaeontology, first published online May 17, 2016, https://doi.org/10.1144/jmpaleo2015-022

Schonikov, E.I. 1973. Ostracoda of the Aral Sea. Zoologicheskii Zhurnal, 52, 1304-1314.

Schön, I., Halse, S. \& Martens, K. 2017. Cyprideis (Crustacea, Ostracoda) in Australia. Journal of Micropalaeontology, first published online January 11 2017, https://doi.org/10.1144/jmpaleo2016-032

Sywula, T., Głazewska, I., Whatley, R.C. \& Moguilevsky, A. 1995. Genetic differentiation in the brackish-water ostracod Cyprideis torosa. Marine Biology, 121, 647-653.

Van Harten, D. 1996. Cyprideis torosa (Ostracoda) revisited. Of salinity, nodes and shell size. In: Keen, M.C. (ed.) Proceedings of the 2nd European Ostracodologists Meeting. British Micropalaeontological Society, London, 191-194.

Vesper, B. 1972a. Zur Morphologie und Ökologie von Cyprideis torosa (Jones, 1850) (Crustacea, Ostracoda, Cytheridae) unter besonderer Berücksichtigung seiner Biometrie. Mitteilungen aus dem Hamburgischen Zoologischen Museum und Institut, 68, 21-77.

Vesper, B. 1972b. Zum Problem der Buckelbildung bei Cyprideis torosa (Jones, 1850) (Crustacea, Ostracoda, Cytheridae). Mitteilungen aus dem Hamburgischen Zoologischen Museum und Institut, 68, 79-94.

Wansard, G., De Deckker, P. \& Julià, R. 2016. Combining the $\mathrm{Mg} / \mathrm{Ca}$ of the ostracod Cyprideis torosa with its ontogenic development for reconstructing a $28 \mathrm{kyr}$ temperature record for Lake Banyoles (NE Spain). Journal of Micropalaeontology, first published online January 19, 2016, https://doi.org 10.1144/jmpaleo2015-009

Wouters, K. 2016. On the modern distribution of the euryhaline species Cyprideis torosa (Jones, 1850) (Crustacea, Ostracoda). Journal of Micropalaeontology, first published online May 3, 2016, https://doi.org/10.1144/jmpaleo2015-02

Wouters, K. 2002. On the distribution of Cyprideis torosa (Jones) (Crustacea, Ostracoda) in Africa, with the discussion of a new record from the Seychelles. Bulletin de l'Institut Royal des Sciences Naturelles de Belgique, Biologie, 72 , 131-140.

Wouters, K. 2003. New records of the genus Cyprideis (Crustacea, Ostracoda) from South Africa. Bulletin de l'Institut Royal des Sciences Naturelles de Belgique, Biologie, 73, 161-165. 